\title{
WHOSE HUMAN RIGHTS? \\ SUFFERING AND RECONSTRUCTION IN POSTWAR SIERRA LEONE
}

Michael Jackson

\begin{abstract}
This article had its beginnings in my conversations and encounters with refugees in Freetown, Sierra Leone, in the wake of that country's decade-long civil war. These experiences made me increasingly concerned at the extent to which our Western rhetoric of suffering and human rights ignores the ways in which Sierra Leoneans understand and address their situation. This led me to see the problem of translation not simply as a matter of doing justice to the speech or writing of others, but as a matter of forestalling the unspoken political and ethical judgements that influence every translation, and that so often mean that not only meanings get lost in translation but also lives, livelihoods, languages and land. I therefore offer a critique of the way human rights is currently invoked to give legitimacy to a kind of moral neo-colonialism in West Africa - a reprise of the theme of the white man's burden that implies that Africans need to be saved from themselves and that we are the ones to do it.
\end{abstract}

\section{INTRODUCTION}

....and I realised then the unmitigable chasm between all life and all print - that those who can, do, those who cannot and suffer enough because they can't, write about it.

William Faulkner, The Unvanquished (1967:262).

Most immediately, the question of translation brings to mind the problems of capturing in the idioms of one language meanings originally expressed in another. Supposedly, words can be found that do justice to the speech or writing that we are subjecting to translation, as well as to the human subjects whose thoughts, feelings, and intentions are conveyed in these spoken or written words. But as anthropologists, we are only too well aware that unspoken 
political and ethical judgements influence every translation, and that not only do meanings get lost in translation but also lives, livelihoods, languages and land. So it is that we dedicate ourselves to the empirical task of listening to and learning from others, a task that makes translation a test of our resolve to grasp, rather than lose or betray, their sense of their existence - and the way the world appears to them.

This talk had its beginnings in my conversations and encounters with refugees in Freetown, Sierra Leone, in the wake of that country's decade-long civil war. This experience led me to become increasingly concerned by the extent to which our Western rhetoric of suffering and human rights ignores the ways in which Sierra Leoneans understand and address their situation. My argument is that the vexed political question of global human rights has to engage far more with ethnographic insights into how human rights are experienced and understood culturally and locally.

Let me begin by emphasising something that struck me years ago, living and working in Kuranko villages - the way people are taught to accept adversity, and endure it. It is the overriding lesson of initiation, when pain is inflicted on neophytes so that they may acquire the virtues of fortitude and imperturbability. Pain is an unavoidable part of life; it can neither be abolished nor explained away; what matters most is how one suffers and withstands it. This is nicely expressed in a Kuranko proverb that exploits the fact that the words dununia ('load') and dunia ('world') are near homonyms - dunia toge ma dunia; a toge le a dununia ('the name of the world is not world; it is load, i.e. the weight of the world is a matter of how one comports oneself). According to this view, life is a struggle between one's inner resources and external conditions. Expressed in a more existential vein, one might say that human existence is a struggle to strike some kind of balance between being an actor and being acted upon. In spite of being aware that eternity is infinite and human life finite, that the cosmos is great and the human world small, and that nothing anyone says or does can immunise him or her from the contingencies of history, the tyranny of circumstances, the finality of death, and the accidents of fate, every human being needs some modicum of choice, craves some degree of understanding, demands some say, and expects some sense of control over the course of his or her own life. In the stories I want to share with you today, this balance between being an actor and being acted upon has been catastrophically lost. After recounting a young Sierra Leonean woman's story about her wartime suffering and her postwar situation, I turn to a consideration of what Luc Boltanski has called suffering at a distance - the kind of suffering that liberal Westerners are wont to experience when confronted 
by the pain, distress, and misery of others, and find themselves at a loss to do anything about it. Finally, I examine the ways in which our responses to their suffering - a process that is analagous to the way we translate unfamiliar texts into a familiar language - effectively blind us to that suffering, and to the ways that others choose to go about the work of reconciliation and rebuilding. In other words, I offer a critique of the way human rights is currently invoked to give legitimacy to a kind of moral neo-colonialism in West Africa - a reprise of the theme of the white man's burden that implies that Africans need to be saved from themselves and that we are the ones to do it.

FINA KAMARA'S STORY

Three years before the war ended, I read a story in the Guardian Weekly under the headline 'Machete Terror Stalks Sierra Leone'. It concerned a rebel attack on the Kuranko village of Kondembaia in April 1998, and its focus was the ordeal of a young Kuranko woman and her six year-old daughter. When I went back to Sierra Leone after the war, I found Fina Kamara living in the so-called amputees camp in Murraytown. Though many of the refugees were living in makeshift dwellings, made of white- and blue-striped UN plastic tarps pulled over lashed poles, Fina occupied a room in a disused barracks.

I recognised her at once from the photo that had appeared in the Guardian, and after I had introduced myself I told her of the fieldwork I used to do in Kondembaia, and the recordings I had made of her uncle's stories. I then showed her the clipping from the Guardian that I had bought with me. She looked at it without emotion or interest before passing it on to the other refugees who, out of curiosity, had now joined us. No one commented.

When I asked Fina if she would mind if I tape-recorded her story, she raised no objection, but wanted to know if she should speak in Krio or Kuranko. I suggested she speak in Kuranko.

We were hiding in the bush for three months, she began. We were afraid the $\mathrm{RUF}^{1}$ might come at any time and attack the town. But then we received messages from Freetown and from есомоG ${ }^{2}$ to come out of the bush and return to town. So we came out of the bush.

One day we went to our farm to plant groundnuts. We returned to town that afternoon. Suddenly, we heard gunshots. Because there were ECOMOG soldiers in Kondembaia, we were used to hearing gunfire, but this time we were confused. 
The RUF came suddenly. They shot many people. They stacked the bodies under the cotton tree. Then they grabbed us. Their leader said they were going to kill us too. But then they sent their boys to bring a knife. My daughter Damba was six. They took her from me and cut off her hand. After that they cut off all our hands. One man died because of the bleeding. We ran. We fell to the ground. After some time we got up. Damba said, Mummy, I am thirsty. By now all the houses were on fire. We went behind one of the houses. One of the RUF boys came and said, What are you doing there? I said, I want to give water to my daughter. I gave Damba some water. Then I sat down and tied her on my back. We began running again, but they stopped us in the backyard of one of the houses. One RUF girl said, You move one step and I will shoot you. I had to go back. But there was a place behind the houses. We went down there. After a while I felt hungry. I found a mango but could not eat because my blood was all over it. A little while later I overheard the RUF saying it was time for them to leave. When they had gone, I found my son, and tied Damba on my back again and went to the bush. From there I came out on the road and sat down. I met my husband and uncle there. Everyone was crying. I told them to stop crying. We went to our farm, and in the morning we set off for Kabala. We did not reach Kabala that day because of the pain. It took us two days. People in Kabala said we were lucky; the Red Cross was there. After treating us they brought us by helicopter to Freetown here. We were taken to Connaught Hospital. They treated us there. Then we were taken to Waterloo. When the RUF invaded Freetown, we had to flee from Waterloo. We fled to the Stadium. From there we were brought to this camp. If you ask me, this is all I know. We were ordinary people, we were farmers, we had nothing to do with the government. Whenever I think about this, and about the time they cut off my hand, and my daughter's hand, only six years of age, I feel so bad. Our children are here now. They are not going to school. Every morning we are given bulgar. Not enough for us. We are really suffering here. We only hope this war will come to an end and that we will be taken back to our own places. If we go back home, we have our own people there who will help us.

Around the time I was visiting refugees in the Freetown camps, I was reading W.G. Sebald's great novel, Austerlitz. At one point in his novel, Sebald's main character recounts the history of the area around London's Liverpool Street Station, in particular of a priory which, until the 17th century, stood on the site of today's main station concourse, and was connected to the hospital for the insane and other destitute persons at Bishopsgate that we remember as Bedlam. Austerlitz recalls how, on his many visits to Liverpool Street station, he would obsessively try to imagine the location of the rooms where the asylum inmates were confined, wondering 'whether the pain and suffering accumu- 
lated on this site over the centuries had ever really ebbed away, or whether they might not still, as I sometimes thought when I felt a cold breath of air on my forehead, be sensed as we pass through them on our way through the station halls and up and down the flights of steps' (2001:183). This image of suffering seeping into the earth, and still haunting the place where it occurred so long ago, is, of course, suggestive of the way that suffering seeps into us, whose historical or social distance from it gives us little immunity from its ghostly influence.

When Bertrand Russell speaks of his 'unbearable pity for the suffering of mankind' or Richard Rorty defines liberals as those for whom cruelty is the worst thing that people can do, or the anthropologist Nancy Scheper-Hughes observes of suffering that 'not to look, not to touch, not to record can be a hostile act, an act of indifference, and of turning away' (1995:418), we glimpse what has been at stake for conscientious intellectuals since the late $18^{\text {th }}$ century, when the modern engagement with human inequality and suffering was first scripted. Until this time, and despite lip service to Christian precepts of mercy and compassion, it was by no means natural or inevitable that people would be moved to pity by the spectacle of human misery. However, by the mid $18^{\text {th }}$ century, Rousseau's 'innate repugnance at seeing a fellow creature suffer' had became commonplace in certain strata of European society, and the cry to end what John Adams called 'the passion for distinction' was critical to both the French and American revolutions (Arendt 1963:66-67 passim). But men like Jean-Jacques Rousseau, Tom Paine, Thomas Jefferson, Robert Owen, and John Adams, though exposed to the spectacle of mass suffering, did not themselves suffer the hardships, pain, and deprivations that moved them so deeply. What was it, then, that drove these men to want to alleviate the suffering of 'the people, en masse, and to create a world in which equal rights included the right to wellbeing and happiness, as well as the right to decide how one was governed? For the Americans, 'the abject and degrading misery' of slavery and AfricanAmerican labour 'was present everywhere' (ibid: 65). For European intellectuals, urban poverty and misery was equally ubiquitous and unavoidable, and it is possible that their revolutionary thinking was driven as much by the sheer awfulness of coexisting with such large numbers of distressed human beings as by enlightenment and compassion. This situation reflected the changes that had taken place in Europe as a result of industrialisation. By the $18^{\text {th }}$ century, the dense concentrations of people in cities, and the intensification of urban misery, meant that the effects of poverty, disease, overcrowding, and pollution could not be ignored.

In 1818, the English poet John Keats, visited the city of Belfast in northern 
Ireland. The scenes that met his eye are pretty much the same that a traveller encounters in many Third World cities today, crowded with youngsters from rural areas seeking their fortune or people displaced by war. Since the turn of the century, rural poverty and the effects of the Industrial Revolution had 'sucked so many people into Belfast that its population had expanded by 50 per cent' (Motion 1997: 279). Keats, travelling with a close friend, Charles Brown, was deeply troubled by the suffering he saw. 'What a tremendous difficulty', he wrote his brother Tom, 'is the improvement of the condition of such people - I cannot conceive how a mind 'with child' of Philosophy could gra[s]p at possibility - with me it is absolute despair' (cited in Motion ibid: 279). But Keats' despair at how this suffering might be alleviated gives way to an acceptance of life's unavoidable hardships, and a fascination with how one might 'convert the brutal facts of life into perceptions which might "do the world some good"' (ibid:301, emphasis added). Subtly, the desire to reform a barbarous social system is tempered by a more fervent desire to transmute the suffering around him into a form that improves his own soul. 'Do you not see how necessary a World of Pains and troubles is to school an Intelligence and make it a soul?' he wrote to his brother George in 1819, observing that this 'system of salvation' was very different from Christianity, and did not 'affront our reason and humanity' (cited in Motion op.cit: 377-378). This turn to inwardness is, of course, characteristic of romanticism. But it is a turn that is born of a frustration to change the world politically. Faced with entrenched inequality, and the impossibility of social change, the romantic falls back on his own emotions, his own thoughts, his own suffering - what Coleridge called 'inner goings-on' and Luc Boltanski calls a 'metaphysics of interiority' (1999:81), and Sartre calls 'magical action' (1948:58-61). That is to say, when action on the world around us proves impossible, we have recourse to action on our own emotions and thoughts, thereby transforming the way we experience the world. Unable to flee an assailant, a person may faint. Unable to win an argument, a person may resort to verbally abusing his opponent. Unable to do anything about an impending crisis, a person may worry himself sick about it, as if this increase in anxiety will make some real difference. Unable to stop thinking about a traumatic event a person may refuse to speak of it, as if silence will make the event go away - a view contained in the English saying Least said, soonest mended.

Time does not allow me to review all these magical strategies, but a brief summary of two may be helpful.

One such strategy is to magic the problem away by merging oneself with it - identifying so completely with the misery around you that the boundary between oneself and the object of one's concern is effectively dissolved. Van 
Gogh provides a poignant example of this empathic identification. Writing to his brother Theo in the winter of 1880, Vincent confesses that his 'only anxiety is: how can I be of use in the world?' At this time he is preparing himself to be an evangelist among the coal miners of the Borinage region, west of Mons. In order to commit himself body and soul to the poor, he feels he must cut himself off from his family, to 'cease to exist' for them. He neglects his appearance, goes hungry and cold, and gives the little he has to peasants and workers. But who is helped by this self-abasing sympathy? What good can come of this identification with the oppressed? Vincent feels imprisoned and melancholic. Frustrated in his efforts to alleviate the misery of humankind, he ends up seeking to annihilate his anguish by steeping himself in the suffering around him. But nothing is really changed. In his act of martyrdom, the martyr has simply made his own troubled conscience disappear by a sleight of hand, donning the sackcloth of those he had set out to save.

Another option consists in intellectualising violence. Here, the lived experience of the sufferer is translated into a purely discursive reality - a problem not so much for administration as for analysis. This use of intellectual techniques for prioritising signification over what Zizek calls 'the senseless actuality' (ibid: 35) of the world, suggests that theoretical meaning may be just one of many consoling illusions for making our relationship with suffering bearable and endurable - taming and domesticating it with words, in order to make it seem safe. But this has real dangers, for, as Veena Das reminds us, in reconstituting suffering as something verbal, we may deny the reality of suffering as effectively as censorship and repression, since discourse all too readily dissolves 'the concrete and existential reality of the suffering victim' (1995:143). Though, in the words of Lawrence Langer, we may call for 'a new kind of discourse to disturb our collective consciousness and stir it into practical action that moves beyond mere pity' (1997:47), it may be more realistic to admit that suffering brings us to limits of language.

Let me now return to Fina's story and how she dealt with suffering.

Three and a half years had passed since Fina Kamara's world fell apart, and she was still struggling to grasp how this could have happened. The rebels came and went within an hour. In this short time they murdered fifty people and mutilated another ten or fifteen. They also set fire to every building in Kondembaia, save the mosque which they used as a kitchen, and the school, the church, and a house where they stashed their belongings. Though Fina had spoken of the RUF, many of the rebels were in fact young junta soldiers, avenging their ouster from power a few weeks earlier when the Nigerian-led 
ECOMOG reinstated the elected government of Ahmad Tejan Kabbah. Unable to defeat the Eсомо soldiers or the Civil Defense militias, they took their revenge on the defenceless people who had allegedly voted for the government, or sheltered and supported the CDF. Of all this, Fina Kamara knew nothing. We are ordinary people, she had told me. All we do is go to our farms.

When I had asked her 'do you think you will ever learn to live with what has happened?' she said 'I will never forget.' I continued:

Would it make any difference to you, if the people that did these dreadful things were punished?

I no longer waste my anger on them. But I will never forget what they did. When they burned my house, how can I forget that? When I look at my hand, how can I ever forget? I feel the pain constantly. Even now, talking to you, I feel it. At times, I can feel my fingers, even though they are not there.

When I saw my old friend Noah the following day, I told him of my visit to the amputee camp, and of Fina Kamara's description of the phantom pain she felt in her hand. The embodied memory of all she had suffered. But I was perplexed, I told Noah, by the way that Fina had explained her feelings toward those who had visited this suffering upon her, and upon her village. I told Noah that when I had asked Fina Kamara what she might do to redress the damage that had been done to her and her daughter she said, There is nothing I can do. And when I asked her what she thought about reconciliation, she used the phrase m'bara hake to an ye. What exactly did she meant by this?

'It's what you might say', Noah said, 'when someone offends or hurts you, and you are powerless to retaliate. If, for instance, someone takes something from you without justification. Or insults and humiliates you for no good reason. Say a hawk came out of the blue and seized one of your chickens. What can you do? You can't get it back. The hawk has flown away. You have no means of hunting it down, or killing it. All you can do is accept, and go on with your life. But you don't really forgive, you don't really forget. You simply accept that there's nothing you can do to change what has happened. Look at me. I have no way of taking revenge on the rebels who took away my livelihood, but at least I can rid myself of them. I can shut them out of my mind. I can expel them from my life'.

Noah's words were reminiscent of a passage in Hannah Arendt's The Human 
Condition (1958:237). Forgiveness implies neither loving those that hate you, nor absolving them from their crime, nor even understanding them ('they know not what they do'); rather, it is a form of redemption, in which one reclaims one's own life, tearing it free from the oppressor's grasp, and releasing oneself from those thoughts of revenge and those memories of one's loss that might otherwise keep one in thrall to one's persecutor forever.

'If I say $i$ hake a to nye', Noah continued, 'I am freeing myself of the effects of your hatred. I am refusing to hate back. But this doesn't mean that justice will not be done. Most of us here feel that God sees everything, and that God will mete out punishment in His own good time. That's why we say God will take out my anger on him (Alatala si n'hake bo a ro). So I might say, I have left it up to God (m'bara n'te to Al'ma). Same as they say in Krio, I don lef mi yon to God. I think this is what Fina Kamara meant. She was not saying that she forgives the RUF, but that she is leaving it up to God to see that justice is done. Because how can you ever be reconciled to someone who has killed your father or cut off your hand? Reconciliation, forgiveness, forgetting ... these are all relative terms. In Sierra Leone right now, we are letting sleeping dogs lie. You understand? We are fed up with the war. Fed up with atrocities. If we talk about the war, it is not because we are plotting revenge or want to prolong the suffering. We simply do not want it to happen again.'

Though Fina Kamara and Noah had found it expedient to give up all thought of payback, this did not mean they they rejected the possibility of retaliation or the principle of lex talionis. Indeed payback is an open and vexed question in Sierra Leone. For who will see that justice is done? How can apologies atone for the material and social losses people have suffered. Who will pay for reparations? And will the trial of war criminals, now under way in Special Courts set up at both national and village levels, simply rub salt into old wounds, stir up bitter memories, cause resentment, and set in train another cycle of violence (Jackson 2002:57, 62, 164-167). The people I spoke to were realists, acutely aware of what they could and could not do. Consider, for instance, the comments of Noah's brother, S.B. Marah, who was a prominent Sierra Leonean politician, and Leader of the House in Ahmad Tejan Kabbah's SLPP government. If S.B. was less forgiving when he spoke of the RUF, it was not because his anger was stronger but because he was in a stronger position. Justice was thus conditional on one's power to see that justice is done. Or, as Noah's put it, 'If you are in a position of power you'll seek revenge, saying "May my hake fall on those who have destroyed the country." His brother echoed this point of view. When I asked S.B. for his opinion of the truth and reconciliation process, he said, 'I come from a warrior family. My ancestors went to 
war. So with this war now, I wanted to fight to the finish. I wanted the fight to go on to the end, until the RUF were defeated. The President knows my views. He knows I was against the Loma peace accord. This was a useless war. The perpetrators must be brought to justice, and not forgiven. They destroyed us. In fact everything I worked for over thirty years they destroyed. So I do not forgive or forget'. S.B.'s attitude to his thirteen-month long detention in 1974, was, however, very different. When, in the course of researching his life-story, I had asked him what he felt as he recounted his experiences in Pademba road prison, and the judicial murder of his peers, he said, 'It is painful, but it has happened, it has happened. But that is the price one has to pay if you go into politics. But the RUF atrocities were something else. Something beyond the pale, something outside the bounds of what was human, and could not be forgiven. Though S.B., Fina Kamara, and Noah were as different as any human beings could be, I had been struck by their sober sense of what, in any given situation, was possible and what was impossible - of where the limits of their freedom lay. All too often in the West, ideas like truth and freedom are discussed in total abstraction. We are encouraged in the belief that there is nothing we cannot do if we put our minds to it. That there is no corner of the universe that is intrinsically beyond our understanding and control. No limit to our power to manipulate genes, to prolong life, to alleviate suffering, and to mete out justice, and to find personal fulfillment.

What also struck me forcibly about Fina Kamara's story was not only her awareness of her own powerlessness, but the absence of any dwelling on the self. There are, I think, two reasons why this was so. First, is the Kuranko habit of recounting one's experience, not as a singular, personal story, based on 'autobiographical memory' but as a series of shared events, involving crucial social relations (Jackson 1989: 20). Thus, Fina and others who suffered in the war were well aware that the violence was arbitrary. If they were victims, it was because the rebels classified everyone who was not for them as being against them, and because they simply happened to be in the wrong place at the wrong time. It was not that they were singled out on account of their specific identity. This is vividly conveyed in the way Fina relates her story. It is only at the moment when her arm is severed, or when she tries to eat the bloody mango, that her narrative consciousness is fully on herself. At other times she is a part of the village, one among many, and she recounts events as they happened to 'us.' As a corollory of this emphasis on 'we' rather than 'I,' Kuranko tend to construct experience as intersubjective rather than intrapsychic, though from an empirical point of view each obviously entails the other. ${ }^{5}$ Alhough people suffered humiliation, bereavement, mutilation and grievous loss in the war no one spoke of unhinged minds, of broken spirits, or of troubled souls. And 
healing was sought, not through words, but deeds. Not through therapy but through things. Fees to send children to school. Cement and roofing iron to rebuild houses. Grain. Micro-credit. Food. Medicines. It may well be that a diagnostic label like Post Traumatic Stress Disorder is empirically justified, ${ }^{6}$ but it imperative that we acknowledge that intrapsychic wounds are not the burning issue for Sierra Leoneans, but rather the material means that are needed to sustain life, and ensure a future for one's children. ${ }^{7}$ This was vividly brought to home to me when Noah spoke about his son and daughter who had been abducted by the RUF. His son managed to escape during a battle to dislodge the Sierra Leone army from the town of Makeni, and returned home to Freetown and his family. Noah told him that he did not want to hear anything of what had happened. It made him feel bad. As for the boy, apart from saying he hated the RUF, and would never forgive them for what they put him through, he craved only that his ignominy not become public knowledge. During the disarmament period, Noah urged him to go and find his weapon and hand it in to the authorities, but his son said 'No, I want no record of the fact that I carried arms; I will not do it, even if I am paid millions of leones'. As for the daughter, she was sexually-abused and traumatised (Noah's word). When she finally came home, she refused to return to school. Like her brother, she was deeply ashamed of what had befallen her. Noah had to 'talk and talk and talk to her' before she enrolled in a Vocational school in Freetown, and did a dressmaking course for a year. Noah told her, 'You are not the only one this happened to. It happened to thousands. So you should return to school. Now, he told me, 'she is doing well at school and going on with her life'.

\section{SIERRA LEONE AND THE DISCOURSE OF HUMAN RIGHTS}

Although the issue of human rights was raised in classical Greek and Roman literature, and promoted in the English Magna Carta of 1215, it is, generallyspeaking, a product of the European enlightenment, culminating in the American Declaration of Independence and Constitution $(1776,1787)$, the French Declaration of the Rights of Man and the Citizens (1789), and the UN Universal Declaration of Human Rights (1948). The increasingly complex legalistic, ethical, and political, human rights discourse of the 19th and 2oth centuries is characterised by a striving for an overarching, disinterested, global point of view that may be made binding for all people, in all cultures, at all times. In other words, the focus is on enshrining human rights in international law, and implementing this law on a global scale. These ambitions have disconcerting echoes of the colonial period - of the 'civilizing mission' of missionaries and colonial administrators, committed to stamping out barbarism in every society but their own. 
Let me begin with the observation that people without 'rights' are the least likely to have their voices heard in the human rights conversation. This is partly because thinking abstractly about their 'rights' is a luxury the oppressed can ill afford. But it is mainly a function of the long standing tendency of Westerners to regard 'them' as victims, who possess neither the material nor intellectual agency to protest their situation, pursue justice, or improve their lot, while casting themselves in the role of saviours. Paradoxically, therefore, the discourse of human rights is rarely the discourse of those without rights; it is the discourse of those who enjoy such rights. It is a discourse, not of the powerless, but of the powerful on behalf of the powerless, who all too often assume some kind of 'moral ownership' of third world suffering as a license to intervene in the administration of third world societies (de Waal 1997: 217).

\section{Consider the Sierra Leonean points of view.}

Like thousands of other Sierra Leoneans who lost limbs, loved ones and livelihoods in the civil war, Fina Kamara did not speak of human rights abuses but of satanay ('evil'). Evil exists. It cannot be comprehended. And there is often little one can do to protect oneself from it, to avenge oneself, or to secure justice if one falls foul of it. Though the violence done to her and her daughter by the RUF was an unprecedented 'evil', that had no parallel in her experience, Fina Kamara responded to it in the same way Kuranko women responded to the unavoidable and everyday hardships of life - with defiant acceptance. For us to categorise the RUF atrocities as 'human rights abuses' is, no doubt, to recognise an important distinction between the kinds of harm that are perpetrated by human agents and natural disasters that cannot be blamed on anyone ('acts of God'). It is, in fact, precisely the distinction Kuranko make between afflictions and illnesses that are caused by sorcery (morgo kiraiye - caused by persons) and afflictions and illnesses that occur, as it were, in the nature of things (altala kiraiya - caused by God). But in practice, it is seldom a cut and dried question of deciding whether misfortunes were caused by God or Man, but deciding the relative weight of these opposing forces - which one was the 'first spear' and which the 'second spear', to use Zande hunting parlance (Evans-Pritchard 1934:59). This decision is never an 'objective' appraisal, since it reflects the subjective capacity of a person to do something about her situation. Thus, Fina Kama, powerless to take punitive action against the people who destroyed her life, acknowledges that her tragedy was caused by human agents, yet invokes God as the agent of retribution.

Whether we invoke the Western or the Kuranko distinction, the critical factor for a sufferer is whether or not he or she can do anything about his or her 
situation - whether the affliction can be cured, whether justice can be done, whether punishment of the perpetrator will make any difference to the victim, and whether redress is possible for what has been lost. To isolate a particular class of affliction, and call it human rights abuses or PTSD may be mere casuistry.

For advocates of human rights, the response to this critique is that though we cannot redress the injustices of the past, we can prevent injustices happening in the future if we create a universal charter and an apparatus for implementing it. The counter-argument is that isolating a particular category of violence under the rubric of human rights abuses distracts us from the conditions that make such abuses inevitable, and from the complex situations in which such human rights abuses arise. It is sometimes important to remind ourselves that upholding human rights does not necessarily protect people from poverty and hunger - the very conditions that often lead to human rights abuses. Despite its 'bad' record on human rights, China had made extraordinary progress in conquering poverty, while, for all its much-vaunted democratic ideals, US domestic policies create a widening gap between haves and have-nots. Second, to speak of a breach of human rights is to imply a distinction between violences that are caused by human agents, and that can therefore be unequivocally and legalistically defined and prosecuted, and those that are too diffuse to be attributed to any single human agent or perpetrator, or redressed by legal means. These are 'the violences of everyday life', as Arthur Kleinman calls them., that encompass the deeply-engrained, disguised, and habitual forms of 'structural' inequality that systematically negate the will and deny agency to vast numbers of people in contemporary societies simply because they are poor, 'coloured', young, infirm, elderly, vagrant, or migrant. Our notion of what constitutes 'violation' or 'human rights abuses' cannot, therefore, be limited to situations in which physical harm is done, for a person's humanity is violated whenever his or her status as a subject is reduced against his or her will to mere objectivity, for this implies that he or she no longer exists in any active social relationship to others, but solely in a passive relationship to himself or herself on the margins of the global realm. The mutilation Fina Kamara suffered at the hands of the RUF were nothing beside the nullifying effects of her prolonged sojourn in a refugee camp where she could neither act on or understand her situation, and where, in the name of humanitarianism, an aid agency (she did not know which one) took Damba to the US, ostensibly for specialist medical treatment, leaving Fina with no way of communicating with her daughter, and no idea when Damba would return to Sierra Leone. For two years I was unable to find out how this unidentified agency had justified such a prolonged separation of mother and daughter, but I recently discovered, much to my sorrow, that 
several child amputees, Damba among them, were taken to the US by a religious group and treated by a Long Island prosthetic specialist who had helped raise money for their trip. She had then been adopted by an American family. As baffled by these events as she had been by the events that had made her a refugee, Fina was willing to accept her daughter's fate, though she asked me why the family in America was going to change Damba's last name, and when she would be free to return to Sierra Leone to see her brother.

Fina's struggle to divine the intentions of this American religious group who took her daughter from her, and the Americans' apparent indifference to the bond between Fina and her daughter brings into poignant relief the way that meaning is a prerogative of power. Whatever Damba's wishes are, whatever Damba means to her mother, and whatever rights Fina has in this matter, fail to register, fail to get recognised. Although I have no way of knowing whether Damba's American parents ever considered the human rights issues raised by this 'adoption', I think it is appropriate to remind ourselves that the road to hell is paved with good intentions, and to rededicate ourselves to the ethnographic task of reflecting critically on what we believe to be right by seeing it from the vantage point of the other.

By focussing on the atrocities caused by the rebels, and on the business of bringing the RUF leadership to justice, we may all too readily overlook the myriad of small wrongs that make up the violences of everyday life in Sierra Leone, and ignore the ways in which Sierra Leoneans have addressed the fall-out from the war. In January this year, in the Kuranko village of Kamadugu Sukurela, where I first did fieldwork in 1969, and which was pillaged and burned to the ground during the war, fifty-eight girls were initiated into womanhood, the first such event in almost ten years. Observing the familiar festivities, I found it impossible not to interpret this coming-together of farflung kin, this post-harvest celebration of communitas and social continuity, as a rite of reconciliation, in which the scars of war were treated and healed. Similar healing underlay the domestic sacrifices of rice flour to the ancestors, and village sacrifices to God. These were the customary ways in which villagers overcame division, and affirmed life against death. Yet this local-level work of reconciliation is simply not recognised, or even known about, by the NGOs and European experts that have impressed on the government of Sierra Leone the need for truth and reconciliation, European-style. There's a radio jingle you hear on Freetown radio these days. 'Come blow your mind, come clear your chest. Truth and Reconciliation - the Commission we come for help we yone, Make peace sidon na Salone.' But as a child ex-combatant said to me, 'I don't want a lot of that kind of talk. I want to forget what happened.' 
Who are we to say that silence is denial, and talk therapeutic? For silence may be, as in Africa, a way of healing and reconciliation, and not a way of evading or repressing an issue. Indeed, it may be a consummate form of coexistence. Speech disperses the world, say the Mande; silence restores wholeness. Speech burns the mouth; silence heals it. Speech builds the village; silence regenerates the world.

On March 11, 2003 the Guardian newspaper announced that the Special Court, established in Sierra Leone under the auspices of the UN, had indicted seven Sierra Leoneans 'for war crimes, crimes against humanity and violations of international humanitarian law committed during the West African country's decade-long conflict' (2003:6). Shortly afterward, the European Union welcomed the 'prompt and diligent action' of Sierra Leone's Special Court, calling it 'an important milestone on the path for peace, justice and reconciliation for the people of Sierra Leone.' In a declaration by the EU's Greek presidency, the European Union reiterated its strong support for the court in its crucial task to bring the main perpetrators of serious violations of international humanitarian law in Sierra Leone to justice' and expressed support for Sierra Leone's Truth and Reconciliation Commission in 'its endeavours to contribute to the healing of the Sierra Leone society.' What neither the Guardian nor the European Union statement mentioned was that of the seven former RUF and AFRC junta leaders indicted by Sierra Leone's war crimes tribunal, two of the former RUF commanders had been about to launch projects funded by the Government's National Committee for Disarmament, Demobilisation and Reintegration (NCDDR), and other ex-rebel commanders were also reportedly working on community development initiatives. 'We actually had already approved four fisheries projects for Issa Sesay, Morris Kallon, Gibril Massaquoi and Eldred Collins,' said NCDDR Executive-Secretary Dr. Francis Kai-Kai. Yet another ex-RUf commander, Augustine Gbao, was already at an 'advanced stage' in implementing an agricultural project in his home village in Kenema District. As for the arrest of Hinga-Norman, who had led the civilian militias in their campaigns against the RUF, many were outraged that someone who helped save the country from destruction should be placed on trial for human rights abuses. ${ }^{8}$

I am not making a case against human rights, per se, but making the point that, historically, countless wrongs have been committed in the name of God, Allah, and Human Rights, and that the human rights discourse in the West often overlooks the way non-Westerners affirm, in practice as well as discourse, our common humanity. I am also making the point that the Western discourse of human rights all too often disguises and perpetuates power inequalities 
between Africa and the West, and, despite its humanitarian rhetoric, continues to see Africa as 'a heart of darkness' that needs the enlightened West to rescue it from its own barbarism. Moreover, by focussing on the spectacles of physical violence (murder, mutilation, torture), the plight of victims, and issues such as 'child soldiers', the mediatised discourse of the West not only sustains its image of Africa as the antithesis of the West, but deflects attention from the ways in which global capitalism, salvationist ideology, and the disaster relief industry actually foster the social, economic and political conditions that doom vast numbers of people to social death, and determine the preconditions for violence.

\section{NOTES}

1 Revolutionary United Front, otherwise known as the rebels.

2 Economic Community of West African States Monitoring Group - a military force, made up mainly of Nigerian troops, that was brought into Sierra Leone to quell the rebellion.

3 Hake is sometimes translated as 'sin', though the word covers a multitude of motives - hatred, ill-will, malice, envy - and distracts from the principle of retributive justice that lies behind it. In Kuranko thought, intersubjective relationships are governed by reciprocity, so that if a person offends, wrongs, or injures another person without justification, the offence calls for payback (tasare). This compensatory action may be effected through several means. It may follow a court hearing, in which case the offender must indemnify the person to whom injury has been caused. It may follow a verbal apology, in which the offender begs forgiveness. It may, if recourse to legal means or the workings of individual conscience are unavailing, lead the injured party to take matters into his own hand and seek sorcery as a form of revenge. Alternatively, if the injured party feels that no worldy agency can secure redress, he may be inclined to leave matters in the hands of God. In a previous discussion of hake (Jackson 1982: 29-30) I speak of automatic redress, in which an unprovoked and unjustified offence will boomerang back against the offender, particularly if the victim is protected by magical medicines. In conversations with Kuranko informants in JanuaryFebruary 2002, however, such redress was thought to require divine agency. As Noah put it, "People feel that God is just and omnipotent. One way or another He'll avenge the crime or wrong-doing." 
4 That all villagers were equal in the eyes of the rebels, may ironically have helped them endure the trauma they experienced, for though RUF violence destroyed the lives of so many, it has reinforced a sense of solidarity among the survivors. This solidarity was clearly evident when the Civilian Defence Force war widows, orphans, and ex-combatants Association was launched in Kabala, northern Sierra Leone, on January 112002 with the aim of rebuilding villagers, clinics, and schools, of offering vocational training in gara-dying, carpentry, and tailoring, and providing medicines and micro-credit to villagers.

5 We in the West dwell much on the self. We make a profession of our wounds. In our stress on psychic inwardness, our own sympathetic suffering all too easily blinds us to those who are really suffering, or making own own feelings, rather than our relations with others, our primary concern. This view informed Desmond Tutu's invocation of the African concept of ubuntu at the South African Truth and Reconciliation Commission - for reconciliation, he argued, required a movement from 'I' to 'we'. More forthrightly, the psychologist Nomfundo Walaza condemned those who put the salving of their own consciences, the saving of their own souls, the absolution of their own guilt, before the actions that would, in concert with others, create a new order that might redeem the order of the past.

6 In a meticulous account of the social history of PTSD, Allan Young argues that this syndrome is 'not timeless, nor does it possess an intrinsic unity. Rather, it is glued together by the practices, technologies, and narratives with which it is diagnosed, studied, treated, and represented, and by the various interests, institutions, and moral arguments that mobilized these efforts and resources' (1995:5). Though historically and socially constructed, this does not mean, however, that what we label trauma or PTSD does not signify profoundly real experiences of human distress (ibid:5-6); it simply means that we should acknowledge that it has the same 'fictive' status as 'witchcraft' among the Azande.

7 These opposing view of reconciliation were ever-present in the Truth and Reconciliation Commission hearings in South Africa. While Archbishop Desmond Tutu, for example, saw reconciliation idealistically, in Christian terms, as a matter of saving one's soul and forgiving one's enemies ('You can only be human in a humane society. If you live with hatred and revenge in your heart, you dehumanize not only yourself, but your community'), Vice-President Thabo Mbeki placed far less emphasis on individual redemption, stressing instead the creation of a new and viable society (Krog 1999:110-111). The same difference in emphasis emerged from debates over the allegedly self-indulgently 'self-centred' attitude of whites (concerned solely with personal amnesty and absolution) and 
the so-called 'we-centredness' of blacks (concerned more with healing a damaged nation through piacular rituals, and new forms of social solidarity and shared belief (Krog op.cit:160-161).

8 Arguing against the widespread assumption that contemporary international humanitarianism 'works' to alleviate poverty and inequality in Africa, Alex de Waal concludes that 'conflicts in Africa can have local solutions, military or political' and suggests that it would be better if the West intervenes less, not more, in these processes (1997: 216).

\section{REFERENCES}

Adorno, Theodor 1998 Critical Models: Interventions and Catchwords (trans. Henry Pickford). Columbia University Press: New York.

Arendt, Hannah 1958 The Human Condition. Chicago: Chicago University Press.

Arendt, Hannah 1963 On Revolution. New York: Viking Press.

Baldwin, James, and Margaret Mead. 1971. A Rap on Race. London: Michael Joseph.

Boltanski, Luc 1999 Distant Suffering: Morality, Media and Politics, (trans. Graham Burchell). Cambridge: Cambridge University Press.

Das, Veena 1995 Critical Events: an Anthropological Perspective on Contemporary India. Delhi: Oxford University Press.

de Waal, Alex 1997 Famine Crimes: Politics and the Disaster Relief

Industry in Africa. African Rights and the International African Institute in association with James Currey (Oxford) and Indiana University Press (Bloomington).

Evans-Pritchard, E. E. 1934 “Zande Therapeutics”. In Evans-Pritchard,

E.E., Firth, Raymond and Malinowski, Bronislaw (eds) Essays Presented to C.G. Seligman. London: Kegan Paul, Trench, Trubner \& Co, pp. 49-61.

Jackson, Michael 1982 Allegories of the Wilderness: Ethics and Ambiguity in Kuranko Narratives. Bloomington: Indiana University Press. 
Jackson, Michael 1989 Paths Toward a Clearing: Radical Empiricism and Ethnographic Inquiry. Bloomington: Indiana University Press.

Jackson, Michael 2002 The Politics of Storytelling: Violence, Transgression, and Intersubjectivity. Museum Tusculanum Press: Copenhagen.

Krog, Antje 1999 Country of my Skull. London: Jonathan Cape.

Langer, Lawrence 1997 The Alarmed Vision: Social Suffering and

Holocaust Atrocity, in Social Suffering, (ed. Arthur Kleinman, Veena Das, and Margaret Lock). Berkeley: University of California Press, pp. 47-65.

Leeming, David 1994 James Baldwin: a Biography. New York: Henry Holt.

Motion, Andrew 1997 Keats. Chicago: University of Chicago Press.

Rorty, Richard 1989 Contingency, Irony, and Solidarity. Cambridge: Cambridge University Press.

Sartre, Jean-Paul 1948 The Emotions. New York: Philosophical Library.

Scheper-Hughes, Nancy 1995 'The Primacy of the Ethical: Propositions for a Militant Anthropology', Current Anthropology 36(1), pp. 409-420.

Sebald, W.G. 2001 Austerlitz. London: Hamish Hamilton.

Young, Allan 1995 The Harmony of Illusions: Inventing Post-Traumatic Stress Disorder. Princeton: Princeton University Press.

Zizek, Slavoj 1991 Looking Awry: an Introduction to Jacques Lacan Through Popular Culture. Cambridge (Mass.): MIT Press. 